\title{
The misperception of the use of ozone in the sanitation processes
}

\author{
Oriana Motta ${ }^{1}$ (D) $\cdot$ Concetta Pironti $^{1} \cdot$ Giuseppina Moccia $^{1} \cdot$ Franceso De Caro $^{1}$
}

Received: 28 December 2020 / Accepted: 11 February 2021 / Published online: 19 February 2021

(C) The Author(s), under exclusive licence to Springer-Verlag GmbH, DE part of Springer Nature 2021

The new worldwide emergency has introduced new urgent disinfection and sanitation measurements of work and professional environments. In particular, the healthcare system was involved in the response to widespread infection with new strategies and the international health organizations introduced more rigorous measures to optimize the quality of care provided to infected patients and to reduce the risk of pathogen transmission to other patients or healthcare operators (Brunetti et al. 2006a, b).

The disinfection and sanitization methods mainly used are heating sterilization, ultraviolet germicidal irradiation, and chemical disinfectants (Moccia et al. 2020a, Motta et al. 2015, 2018, Proto et al. 2016), which have been proposed for work environments and surfaces, including furniture, work devices, non-disposable work tools, and clothing to prevent the spread of the new coronavirus responsible of the SARS$\mathrm{CoV}-2$ related disease. In this context, ozone gained growing interest and it was considered among the best solutions to air disinfection in critical environments, such as intensive care units and/or surgery rooms (Moccia et al. 2020b). Ozone has proven to be highly effective against bacteria, fungi, and molds and inactivating viruses both on the surfaces and suspended in the air. Manning et al. described the possibility of using ozone disinfection of N95 respirators during a shortage of personal protective equipment (PPE) (Manning et al. 2020). In recent months, on international markets, the growing presence of devices, such as ozone generators or electrostatic air purifiers, has been detected. Ozone is generated in situ using dried ambient air as a precursor with three typical phases: the conditioning phase, in which ozone is injected into the room to be disinfected until the desired ozone

Responsible Editor: Philippe Garrigues

Oriana Motta

omotta@unisa.it

1 Department of Medicine Surgery and Dentistry "Scuola Medica Salernitana”, University of Salerno, via S. Allende 1, 84081 Baronissi, (SA), Italy concentration is reached; the treatment phase, lasting for the time necessary for the disinfection; the ventilation or ozone conversion phase, which guarantees the elimination of ozone from the room until the concentration required for the workers' safety is reached. However, the correct use of ozone is related to many factors, i.e., ozone concentration, the temperature of the environment, humidity of the environment, and exposure time. Although ozone gas is useful in air decontamination processes, it presents risks for the safety and health of workers who carry out the process if it is not properly handled. Therefore, the community legislation requires mandatory training courses of personnel and the traceability of the intervention done for correct application in the workplaces.

Inhalation of ozone vapors is the main health risk since the damage induced by this gas is mainly borne by the respiratory system: breathing (e.g., shortness of breath and pain when taking a deep breath) and inflammation of the airways, asthma, emphysema, and chronic bronchitis (chronic obstructive pulmonary disease (COPD)); cardiovascular effects, increased heart rate and diastolic pressure, vascular oxidative stress, inflammation, and decreased heart rate variability; long-term exposure to ozone is likely to be one of many causes of premature deaths, and the evidence is stronger for mortality due to respiratory illnesses (Anenberg et al. 2009); reactions with skin lipids by increasing concentrations of squalene ozonolysis products in the gas phase; children are at increased risk from ozone exposure, as children have a relatively higher dose per body mass and children's lung is still developing. Ozone is also a strong oxidizing agent, reacts violently with organic compounds such as benzene, ethylene, dienes, and alkanes, and therefore it is necessary to take adequate safety measures during its use. In air pollution epidemiologic studies, environmental concentrations were used as 3a proxy for exposure or dose. This approach did not consider inter- and intra-person differences in breathing rate and different concentrations between indoor and outdoor environments. In this case, ozone has unique characteristics that can lead to substantial errors for using ambient ozone concentration as a proxy for dose. The 
workers dedicated to disinfection and sanitization operations represent the most critical point in the safety sanitizing processes of environments. All people involved have to do a training course and follow 3a protocol to carry out the sanitization operations safely, guaranteeing a result capable of satisfying the requirements, the expected quality levels, and the objectives of the activity carried out. Ozone generators must ensure the achievement of correct ozone concentration for the sanitization process and removal of the residual ozone using catalytic converters before the use of rooms.

Furthermore, most of the ozone studies focused on outdoor exposure and ozone already existing in environments and/or produced by the atmospheric pollution (Zhang et al. 2019); the evidence on human health of the effects of indoor produced ozone is still unappreciated, and the recent influence of sanitization processes is unclear. Considering the growing use of ozone generators, even at domestic levels, a large fraction of total ozone exposure can occur indoors; thus, it is necessary to do studies on human health after indoor ozone exposure and to raise awareness to people of the risks involved for public health protection.

Author contribution $\mathrm{OM}$ and $\mathrm{CP}$ developed the concept and drafted the manuscript; OM, CP, GM, and FDC edited and revised manuscript; OM, $\mathrm{CP}, \mathrm{GM}$, and FDC approved the final version of the manuscript.

The manuscript was written through the contributions of all authors. All the authors have given approval to the final version of the manuscript

Funding This work was financially supported by Fondi di Ateneo per la Ricerca di Base (FARB 2017) University of Salerno

Data Availability Not applicable

\section{Declarations}

Ethics approval and consent to participate Not applicable

Consent for publication Not applicable

Conflict of interest The authors declare no competing interests.

Abbreviations SARS-CoV-2, severe acute respiratory syndrome coronavirus 2; COVID-19, coronavirus infectious disease 2019; PPE, personal protective equipment; COPD, chronic obstructive pulmonary disease

\section{References}

Anenberg SC, West JJ, Fiore AM, Jaffe DA, Prather MJ, Bergmann D, Cuvelier K, Dentener FJ, Duncan BN, Gauss M, Hess P, Jonson JE, Lupu A, MacKenzie IA, Marmer E, Park RJ, Sanderson MG, Schultz M, Shindell DT, Szopa S, Vivanco MG, Wild O, Zeng G (2009) Intercontinental impacts of ozone pollution on human mortality. Environ Sci Technol 43(17):6482-6487. https://doi.org/10. $1021 / \mathrm{es} 900518 \mathrm{z}$

Brunetti L, Santoro E, Cavallo P, Boccia G, Motta O, Capunzo M (2006a) Two-years surveillance of fungal contamination in three hospital departments in Campania region. J Prev ed Hyg 47(1):2225

Brunetti L, Santoro E, De Caro F, Cavallo P, Boccia G, Capunzo M, Motta O (2006b) Surveillance of nosocomial infections: a preliminary study on hand hygienecompliance of healthcare workers. J Prev Med Hyg 47(2):64-68

Manning EP, Stephens MD, Patel S, Dufresne S, Silver B, Gerbarg P, Gerbarg Z, Dela Cruz C, Sharma L (2020) Disinfection of N95 respirators with ozone. medRxiv:20097402. https://doi.org/10. 1101/2020.05.28.20097402

Moccia G, Motta O, Pironti C, Proto A, Capunzo M, De Caro F (2020a) An alternative approach for the decontamination of hospital settings. J Infect Public Health. https://doi.org/10.1016/j.jiph.2020.09.020

Moccia G, De Caro F, Pironti C, Boccia G, Capunzo M, Borrelli A, Motta O (2020b) Development and improvement of an effective method for air and surfaces disinfection with ozone gas as a decontaminating agent. Medicina 56:578. https://doi.org/10.3390/medicina56110578

Motta O, Zarrella I, Cucciniello R, Capunzo M, De Caro F (2018) A new strategy to control the proliferation of microorganisms in solid hospital waste and the diffusion of nosocomial infections Le Infezioni in Medicina 26(3):210-215

Motta O, Zarrella I, Cucciniello R, Vigliotta G, Proto A (2015) Study of the antibacterial activity in the gas phase of a chemical formulation for household waste management. Letters in Applied Microbiology 60(3):223-228

Proto A, Zarrella I, Cucciniello R, Pironti C, De Caro F, Motta O (2016) Bactericidal and fungicidal activity in the gas phase of sodium dichloroisocyanurate (NaDCC). Curr Microbiol 73:287-291. https://doi.org/10.1007/s00284-016-1040-x

Zhang J, Wei Y, Fang Z (2019) Ozone pollution: a major health hazard worldwide. Front Immunol 10:2518. https://doi.org/10.3389/ fimmu.2019.02518

Publisher's note Springer Nature remains neutral with regard to jurisdictional claims in published maps and institutional affiliations. 